\title{
Pituitary Adenylyl Cyclase-Activating Polypeptide Stimulates DNA Synthesis But Delays Maturation of Oligodendrocyte Progenitors
}

\author{
Matthew Lee, ${ }^{1}$ Vincent Lelièvre, ${ }^{1}$ Paul Zhao, ${ }^{1}$ Mike Torres, ${ }^{2}$ Williams Rodriguez, ${ }^{1}$ Ji-Yun Byun, ${ }^{1}$ \\ Sameer Doshi, ${ }^{1}$ Yevgenyia Ioffe, ${ }^{1}$ Gauree Gupta, ${ }^{1}$ Araceli Espinosa de los Monteros, ${ }^{1}$ Jean de Vellis, ${ }^{1}$ and \\ James Waschek ${ }^{1}$ \\ ${ }^{1}$ Departments of Neurobiology and Psychiatry and Mental Retardation Research Center and ${ }^{2}$ Department of Biological \\ Chemistry, University of California, Los Angeles, Los Angeles, California 90024-1759
}

\begin{abstract}
The neuropeptide pituitary adenylyl cyclase-activating peptide (PACAP) and one of its receptors $\left(\mathrm{PAC}_{1}\right)$ are expressed in embryonic neural tube, where they appear to regulate neurogenesis and patterning. We now show that $\mathrm{PAC}_{1}$ gene expression is also present in neonatal rats in the ventricular and subventricular zones and in the optic chiasm, areas that are rich in oligodendrocyte (OL) progenitors (OLP). Because actions of PACAP on OLP have not been reported, we examined the effects of PACAP on the proliferation of purified OLP in culture and on myelinogenesis in cerebellar slices. Northern analyses on total RNA from purified glial cell subtypes revealed an abundant $7 \mathrm{~kb}$ hybridizing transcript in OLP, which was confirmed to correspond to the $\mathrm{PAC}_{1}$ receptor by reverse transcription-PCR. The presence of this receptor was also corroborated by radioligand binding and CAMP assay. In cultured
\end{abstract}

The neuropeptide pituitary adenylyl cyclase-activating peptide (PACAP) belongs to a peptide family that includes secretin, glucagon, growth hormone-releasing factor, and vasoactive intestinal peptide (VIP) (Arimura, 1998). PACAP is known to interact via seven transmembrane-spanning domain G-proteincoupled receptors (Rawlings, 1994; Harmar et al., 1998). Two PACAP receptors $\left(\mathrm{VPAC}_{1}\right.$ and $\mathrm{VPAC}_{2}$ ) have high affinity for both VIP and PACAP, whereas a third PACAP receptor $\left(\mathrm{PAC}_{1}\right)$ binds only PACAP with high affinity. Activation of PACAP and VIP receptors typically leads to a robust $\mathrm{G}_{\mathrm{s}}$-mediated cAMP elevation (Arimura, 1998). However, $\mathrm{PAC}_{1}$ receptors are in many cases linked to other signaling pathways such as phospholipase $\mathrm{C}$, phosphoinositol 3-kinase, mitogen-activated protein kinase, and calcium mobilization (Rawlings, 1994). This may be explained in part by the presence of eight known $\mathrm{PAC}_{1}$ receptor splice variants that couple alternatively to $G_{i}$ and $G_{q}$ but also exhibit different affinities for various PACAP-related ligands (Spengler et al.,

\footnotetext{
Received Dec. 19, 2000; revised Feb. 2, 2001; accepted Feb. 23, 2001.

This work was supported by National Institutes of Health Grants HD06576, HD34475, and HD0461 and National Institutes of Health Training Grant T32HD07032 (M.L.). We thank Ruth Cole, Ramin Nazarian, and Joanna Du for providing assistance on cell culture and proliferation and binding studies, Drs. Beth Marbois and Leonard Rome for advice on the in vitro cerebellar slice sulfate incorporation assay, and Dr. Ernesto Bongarzone for assistance in in situ hybridization photography.

M.L. and V.L. contributed equally to this work.

Correspondence should be addressed to Dr. James Waschek, Department of Psychiatry, Mental Retardation Research Center, University of California, Los Angeles, Los Angeles, CA 90024-1759. E-mail: jwaschek@mednet.ucla.edu. Copyright (C) 2001 Society for Neuroscience $0270-6474 / 01 / 213849-11 \$ 15.00 / 0$
}

OL, receptor density decreased during maturation but was partially counterbalanced by the appearance of sites that bound both PACAP and the related peptide vasoactive intestinal peptide. PACAP increased DNA synthesis in OLP cultures almost twofold and increased the bromodeoxyuridine-labeling index in O4-positive OLP. PACAP treatment also resulted in decreased sulfate incorporation into sulfatide in cultures of differentiating OL. The PACAP effect on sulfatide synthesis was fully reproduced in a cerebellar explant model. These findings indicate that PACAP may act at two stages during OL development to (1) stimulate proliferation and (2) delay maturation and/or myelinogenesis.

Key words: PACAP receptors (PAC 1 ); PACAP; oligodendrocytes; proliferation; $C A M P$; myelination
1993; Chatterjee, 1996; Pantaloni et al., 1996; Dautzenberg et al., 1999).

Neuropeptides in the PACAP family and their receptors are highly conserved from protochordates to humans and are widely expressed in the nervous system (McRory and Sherwood, 1997; Hu et al., 2000a,b). It is well accepted that neuropeptides released from specific axonal terminals act as neurotransmitters, neuromodulators, or autocrine/paracrine factors that interact with various neuronal, glial, neuroendocrine, and immune cell populations (Martin et al., 1992; De la Fuente et al., 1996; Legradi et al., 1998; Shibuya et al., 1998; Otto et al., 1999). Interaction of peptides with receptors on target cells may result in modulation of membrane potentials and activation of intracellular signaling systems leading to physiological responses such as release of neurohormones or neurotransmitters (Rawlings and Hezareh, 1996).

Recent data suggest that PACAP exerts developmental actions. PACAP gene expression and PACAP immunoreactivity are widely distributed in neurons within the embryonic and neonatal rat brain (Nielsen et al., 1998a,b; Waschek et al., 1998; Skoglosa et al., 1999). Activation of VIP and PACAP receptors has been shown to regulate proliferation of developing neuroblasts in vitro and in vivo (Pincus et al., 1990; $\mathrm{Lu}$ and DiCicco-Bloom, 1997; Waschek et al., 1998; Vaudry et al., 1999; DiCicco-Bloom et al., 2000). In addition, neuroprotective roles for VIP and PACAP have been proposed (for review, see Waschek, 1996; Lindholm et al., 1998). For example, VIP and/or PACAP have been shown to stimulate neuronal survival directly (Pincus et al., 1990; DiCiccoBloom et al., 2000) and also to influence survival via the glial cell 
release of neurotrophic factors (Brenneman et al., 1987). Yet other studies suggest that VIP/PACAP receptors might be involved in astroglial development (Zupan et al., 1998) and in microglia function (Kong et al., 1999; Kim et al., 2000). To support these findings, $\mathrm{PAC}_{1}$ receptor gene expression has been detected by reverse transcription (RT)-PCR in purified astrocytes (Grimaldi and Cavallaro, 1999) and microglia cultures (Kim et al., 2000). Furthermore, glial tumor cells (including astroglioma and oligodendroglioma cells) express $\mathrm{PAC}_{1}$ receptors (Vertongen et al., 1995). Despite these data, neither $\mathrm{PAC}_{1}$ receptors nor PACAP actions have yet been reported in the oligodendrocytes (OL) or OL progenitors (OLP). The results reported here provide the first evidence that PACAP receptors are present on OLP and that PACAP plays a role in OL development and myelinogenesis.

\section{MATERIALS AND METHODS}

\section{Cell and tissue preparations}

Purified OLP cultures were prepared from neonatal Wistar rats $(<24 \mathrm{hr}$ old) as described previously (McCarthy and de Vellis, 1980) and as modified by Cole and de Vellis (1989). Briefly, OLP were purified by differential adhesion and plated in poly-D-lysine-coated culture flasks. Cells were cultured in DMEM and Ham's F12 medium (supplemented with $1.2 \mathrm{gm} / 1 \mathrm{NaHCO}_{3}, \mathrm{pH} 7.4,15 \mathrm{~mm}$ HEPES buffer, and $10 \%$ fetal bovine serum) for specified time periods $(1,2,5$, and $10 \mathrm{~d})$ to examine OLP at various developmental stages. In longer-term cultures, the medium was changed every $3 \mathrm{~d}$. At the specified time period, cells were directly harvested for RNA extraction or replated into 24-well tissue culture plates at $\sim 0.1 \times 10^{6}$ cells/well $\left(50,000 \mathrm{cells} / \mathrm{cm}^{2}\right)$ for other studies. That OLP differentiated appropriately into OL under these conditions was confirmed by the fact that $>95 \%$ of cells stained positive for myelin basic protein (antibody provided by Dr. A. Campagnoni, University of California, Los Angeles) after $10 \mathrm{~d}$ in culture. In addition, MBP levels increased $>10$-fold over the $10 \mathrm{~d}$ period as determined by Western blot (data not shown).

For slice cultures, cerebella were dissected from neonatal Wistar rat pups ( $<24 \mathrm{hr}$ old) (Notterpek et al., 1993). Meninges were carefully removed, and tissue was incubated in Liebovitz's medium (Life Technologies, Gaithersburg, MD). Cerebella were mounted on a sterile Aclar square and placed on a McIlwain tissue chopper for sectioning. Sagittal slices of 300-400 $\mu \mathrm{m}$ thickness (12-16 slices per cerebellum) were cut, avoiding the buds of the lateral lobes. Isolated slices were plated into poly-D-lysine-coated four-well plates and incubated in DMEM-F12 media containing $10 \%$ heat-inactivated horse serum, $20 \%$ fetal bovine serum, glucose $(4.1 \mathrm{mg} / \mathrm{ml})$, and insulin $(15.6 \mu \mathrm{g} / \mathrm{ml})$. Slices were cultured for 3 weeks in decreasing concentrations of fetal bovine serum according to the protocol of Notterpek et al. (1993).

\section{In situ hybridization}

One-day-old neonatal rat brains were perfused and then fixed with $4 \%$ paraformaldehyde (freshly prepared in DEPC-treated $\mathrm{H}_{2} \mathrm{O}$ ). For cryoprotection, tissues were equilibrated in $30 \%$ sucrose (PBS) and then frozen in OCT. Tissue was sectioned sagittally at $10-12 \mu \mathrm{m}$ thickness, mounted on Superfrost Plus slides (Fisher Scientific, Houston, TX), and then stored at $-70^{\circ} \mathrm{C}$ until use. Preparation of the sense and antisense ${ }^{33} \mathrm{P}$-labeled riboprobes from the $\mathrm{PAC}_{1}$ receptor cDNA (Pisegna and Wank, 1993) and in situ detection were performed as described previously (Waschek et al., 1998). Slides were dipped in Kodak NTB2 emulsion. After development, slides were examined with a Zeiss Axiovert 135M microscope equipped with the Spot Cooled Color Digital Camera (Diagnostic Instruments, Inc.).

\section{Northern analyses}

Cultures of OLP, astrocytes, and microglia with a purity $>95 \%$ were prepared from mixed glial cultures by differential plating as described previously (McCarthy and de Vellis, 1980; Cole and de Vellis, 1989). Purified OLP and microglia were harvested on the sixth day after plating. The remaining astrocytes were also harvested at this time. RNA was extracted from these cultures by the method of Chomczynski and Sacchi (1987). Total RNA (30 $\mu \mathrm{g} / \mathrm{lane}$ ) was subjected to electrophoresis $(1.2 \%$ agarose, 3-[ $\mathrm{N}$-morpholino]propanesulfonic acid, and $2 \%$ formaldehyde gel) and transferred to a nylon membrane (Magna; Micron Separations, Inc.). The membrane was baked at $80^{\circ} \mathrm{C}$ for $30 \mathrm{~min}$ and then UV cross-linked. Sequential hybridizations were performed with the following cDNA probes: rat $\mathrm{PAC}_{1}$ (Waschek at al, 1998), rat $2^{\prime} 3^{\prime}$ cyclic nucleotide $3^{\prime}$ phosphodiesterase (CNPase) (Bernier et al., 1987), and mouse GFAP (Kashima et al., 1993). Between hybridizations, the blot was stripped by incubating twice in a solution containing $96 \%$ formamide, $10 \mathrm{~mm}$ Tris, $\mathrm{pH} 8.0$, and $10 \mathrm{~mm}$ EDTA for $30 \mathrm{~min}$ at $65^{\circ} \mathrm{C}$. Prehybridizations were performed at $42^{\circ} \mathrm{C}$ for $30 \mathrm{~min}$ in ULTRAhyb (Ambion); hybridizations were overnight at $42^{\circ} \mathrm{C}$ in the same buffer but containing $0.2 \times 10^{6} \mathrm{cpm} / \mathrm{ml}$ probe, labeled with $\left[\alpha-{ }^{32} \mathrm{P}\right] \mathrm{dCTP}$ to a specific activity of $2 \times 10^{9} \mathrm{cpm} / \mu \mathrm{g}$ using the Random primers DNA Labeling System (Life Technologies). After hybridization, the blot was washed in $2 \times \mathrm{SSC}$ and $0.1 \%$ SDS (twice for $5 \mathrm{~min}$ at $42^{\circ} \mathrm{C}$ ) and then in $0.2 \times$ SCC and $0.1 \%$ SDS (twice for $15 \mathrm{~min}$ at $42^{\circ} \mathrm{C}$ ) and then exposed for $24-48 \mathrm{hr}$ in a PhosphorImager screen (Molecular Dynamics, Sunnyvale, CA). Signals were analyzed with ImageQuant software.

\section{Binding studies}

Binding assays were performed in triplicate as described by Lelièvre et al. (1996). Briefly, cells plated in 24-well plates were washed and preincubated with fresh medium for $15 \mathrm{~min}$ at $37^{\circ} \mathrm{C}$. Culture medium was removed and replaced with $270 \mu \mathrm{l}$ of $4^{\circ} \mathrm{C}$ binding medium (DMEM, HEPES, BSA, and protease inhibitors) containing $30,000 \mathrm{cpm}$ of radiotracer ( ${ }^{125} \mathrm{I}$-PACAP; $2200 \mathrm{Ci} / \mathrm{mmol}$; NEN Life Sciences) and $30 \mu \mathrm{l}$ of native peptides at the specified concentrations. Cells were incubated at $4^{\circ} \mathrm{C}$ for $2 \mathrm{hr}$, washed with a solution of $0.1 \%$ BSA in PBS $(0.05 \mathrm{M}), \mathrm{pH} 7.4$, and then lysed with $300 \mu \mathrm{l}$ of $\mathrm{NaOH}(0.5 \mathrm{M})$ and transferred into $5 \mathrm{ml}$ tubes and counted in a gamma counter (WALLAC Oy, Turku, Finland).

\section{cAMP measurements}

OLP and differentiated OL were plated in 24-well plates at a density of 100,000 cells/well $\left(50,000\right.$ cells $\left./ \mathrm{cm}^{2}\right)$. After $12 \mathrm{hr}$, cells were pretreated with $10 \mu \mathrm{M}$ isobutylmethylxanthine for $20 \mathrm{~min}$. Neuropeptides were then added for another $20 \mathrm{~min}$ at $37^{\circ} \mathrm{C}$. Cells were then lysed, and the cAMP radioimmunoassay (NEN Life Sciences) was performed as described previously (Vertongen et al., 1996).

\section{$\left[{ }^{3} H\right]$ Thymidine incorporation assay}

Freshly prepared OLP cultures were initially plated into $75 \mathrm{~cm}^{2}$ flasks. On the following day, OLP were replated into 24 -well plates at a density of 50,000 cells/well $\left(25,000\right.$ cells $\left./ \mathrm{cm}^{2}\right)$. The replating used the same medium that was used in other experiments but that contained only $2 \%$ fetal bovine serum (the concentration of serum was lowered to reduce the basal proliferation). On the following and subsequent $2 \mathrm{~d}$, neuropeptides were added at the specified concentrations. The last peptide addition was followed $1 \mathrm{hr}$ later with the addition of $1 \mu \mathrm{Ci}$ of $\left[{ }^{3} \mathrm{H}\right]$ thymidine to each well. Fourteen hours later, cells were harvested. Incorporated $\left[{ }^{3} \mathrm{H}\right]$ thymidine (DuPont NEN) was precipitated by TCA and assayed as described previously (Lelièvre et al., 1998).

\section{Determination of labeling index}

Bromodeoxyuridine labeling. Freshly isolated OLP were plated on polyD-lysine-coated (P-6407; Sigma, St. Louis, MO) coverslips in $10 \%$ fetal bovine serum. Two hours later, the medium was diluted with an equal volume of glial development medium (GDM) (Yonemasu et al., 1998). This adjustment was made to increase cell adhesion to coverslips. After an additional $4 \mathrm{hr}, 10 \mu \mathrm{M}$ bromodeoxyuridine (BrdU; Boehringer Mannheim, Indianapolis, IN) was added along with either PACAP (100 nM) or vehicle.

Colocalization of BrdU with specific glial cell markers. After $18 \mathrm{hr}$ of treatment, cells were fixed with 3.7\% formaldehyde (Fisher Scientific) in PBS for $10 \mathrm{~min}$ and then stored at $4^{\circ} \mathrm{C}$. For immunofluorescence detection, OLP were washed three times with $4^{\circ} \mathrm{C}$ PBS and then incubated in $-20^{\circ} \mathrm{C}$ methanol for $20 \mathrm{~min}$. Cells were then washed three times with PBS, treated with $1 \%$ Triton $\mathrm{X}-100$ in PBS for $20 \mathrm{~min}$ at $37^{\circ} \mathrm{C}$, and then transferred to room temperature for $10 \mathrm{~min}$. Primary antibodies to glial markers were added along with the anti-BRDU antibody as follows: O4 [1:15; supernatant of hybridoma (provided by Dr. S. Pfeiffer, University of Connecticut)], polyclonal anti-GFAP (1:100; catalog \#G-9269; Sigma), and anti-ED-1 (1:100; catalog \#MCA341; Serotec, Indianapolis, IN). Visualization of $\mathrm{O} 4$ was performed using goat anti-mouse IgM AMCA (catalog \#1 110075 075; Jackson ImmunoResearch, West Grove, PA). Anti-GFAP and anti-ED-1 used goat anti-rabbit Texas Red (catalog 
\#1 111075 075; Jackson ImmunoResearch) and goat anti-mouse IgG FITC (catalog \#F-9006; Sigma), respectively. Detection of BrdU was performed according to the manufacturer's protocols (BrdU Labeling and Detection Kit 1, catalog \#1296 736; Boehringer Mannheim). Images were acquired on a Zeiss microscope equipped with a Hamamatsu C5810 Color Camera.

Calculation of labeling index in OLP precursors. The number of BrdU+/ $\mathrm{O} 4+$ and $\mathrm{BrdU}-/ \mathrm{O} 4+$ cells was counted manually in 10 random fields in both control and PACAP-treated cultures. The OLP-labeling index in each field was calculated as the number of $\mathrm{BrdU}+/ \mathrm{O} 4+$ cells divided by the total number of $\mathrm{O} 4+$ cells (i.e., sum of BrdU $+/ \mathrm{O} 4+$ and $\mathrm{BrdU}-/$ $\mathrm{O} 4+$ cells). Mean values for control and PACAP-treated cultures were compared using the $t$ test.

\section{In vitro cerebellar myelination assay}

Seven-day-old OL cultures and cerebellar slice cultures were prepared and treated with peptides or drugs for the next $14 \mathrm{~d}$ and assayed for sulfatide synthesis (Rome et al., 1986; Notterpek et al., 1993). Medium was changed every $2 \mathrm{~d}$ during treatments. Before harvest, cultures were maintained for $48 \mathrm{hr}$ in complete low-sulfate DMEM and F12 growth media in the presence of $5 \mu \mathrm{Ci} /$ well $\left[{ }^{35} \mathrm{~S}^{2} \mathrm{NaSO}_{4}(43 \mathrm{Ci} / \mathrm{mg}\right.$; ICN). Then, sulfolipids were extracted and assayed as described previously (Cardwell and Rome, 1988). This assay was shown by TLC to measure sulfate incorporation specifically into sulfatide, excluding other molecular species such as gangliosides (data not shown). As an experimental control, a mouse monoclonal galactocerebroside/sulfatide (GC) antibody, shown previously to inhibit differentiation (and therefore sulfate incorporation) (Ranscht et al., 1982; Notterpek et al., 1993), was added at $15 \mu \mathrm{l} /$ well to some cultures. For each experimental time point, four cultures were used, and each time point was repeated at least three times.

\section{RESULTS}

\section{Expression of $\mathrm{PAC}_{1}$ mRNA in areas rich in OLP}

In situ hybridization for the $\mathrm{PAC}_{1}$ receptor was performed on frozen sagittal brain sections of rats on postnatal day 0.5 (P0.5), a time when neurogenesis is virtually complete. The analyses were focused on regions containing the ventricular and subventricular zones (VZ and SVZ, respectively) and on the optic chiasm and adjoining optic nerve. Cells in the $\mathrm{VZ}$ at this stage appear to generate primarily glial progenitors that then populate the SVZ (Parnavelas, 1999). The SVZ, on the other hand, contains high numbers of OLP, which proliferate extensively in this region before migrating to the cerebral cortex (Paterson et al., 1973; Levison and Goldman, 1993; Parnavelas, 1999). The optic chiasm and adjoining optic nerve contain proliferating OLPs that are believed to give rise to the oligodendrocytes in the optic nerve (Skoff et al., 1980; Raff et al., 1984; Small et al., 1987).

As shown previously at earlier stages in embryonic mice (Waschek et al., 1998), PAC $_{1}$ gene transcripts in postnatal rats were abundant and uniformly distributed in the VZ (Fig. $1 A-D$ ). $\mathrm{PAC}_{1}$ signals were also uniformly distributed over the SVZ in postnatal rats, but at a lower level (Fig. 1B,D). Moreover, dense accumulations of silver grains appeared to be present over some cells in the SVZ (Fig. 1B,D, arrows). In contrast, no specific labeling was observed in sections hybridized with a sense probe (Fig. 1E,F). Near the base of the forebrain, $\mathrm{PAC}_{1}$ gene transcripts were clearly seen to be clustered over individual cells in the optic chiasm and adjoining optic nerve (Fig. $2 A, B$ ). Again, no specific labeling was observed in nearby sections hybridized with a sense probe (Fig. $2 C, D)$. Overall the data indicate that specific $\mathrm{PAC}_{1}$ receptor gene transcripts are present in regions of the neonatal brain known to give rise to OL.

\section{Expression of the $\mathrm{PAC}_{1}$ receptor gene in purified OLP}

To determine whether $\mathrm{PAC}_{1}$ receptors are expressed specifically in OLP, we isolated and cultured OLP, astrocytes, and microglia from $\mathrm{P} 0.5$ rat cortices by methodology established previously and validated in this laboratory (McCarthy and de Vellis, 1980; Cole and de Vellis, 1989; Liva et al., 1999). The bipolar morphology of OLP after $24 \mathrm{hr}$ in culture is shown in Figure $3 A$ and is essentially the same as that reported by Reynolds and Wilkin (1990) under similar conditions. Northern analyses were performed on total RNA prepared from various purified glial cell subtypes using the $\mathrm{PAC}_{1}$ receptor cDNA, as well as cDNA markers for OLP (CNPase) and astrocytes (GFAP). A transcript hybridizing to the $\mathrm{PAC}_{1}$ probe was clearly detected in cultured OLP at a size of $7 \mathrm{~kb}$ (Fig. 4, top), similar to that reported in the adult rat brain and other tissues (Hashimoto et al., 1993). On the other hand, the $\mathrm{PAC}_{1}$ mRNA was barely detected in total RNA from purified astrocytes and was not detectable in microglia by this analysis. To confirm that these cultures were highly enriched in the desired cell types, the blot was subsequently hybridized to specific glial cDNA markers. A cDNA probe for CNPase, a relatively specific OLP marker, hybridized strongly and specifically to RNA from purified OLPs, whereas a GFAP cDNA probe, an astrocytespecific marker, hybridized strongly and specifically to RNA from astrocytes (Fig. 4, middle, bottom). We were unable to identify a cDNA probe specific for microglia; however, these microglial cultures exhibited very weak GFAP and CNPase mRNA signals and were $95-99 \%$ pure as judged by immunohistochemical staining with the microglia marker ED-1, as shown previously by Liva et al. (1999). Thus, PAC $_{1}$ gene transcripts were abundant in OLP cultures, and their detection was not likely because of contamination of OLP cultures with astrocytes or microglia. To confirm that the hybridizing band in OLP RNA represented an authentic $\mathrm{PAC}_{1}$ gene transcript, RNA from OLP was also analyzed by RT-PCR. Primers were selected that spanned the $\mathrm{N}$ terminal (containing the primary ligand-binding sequences) of the receptor. These primers are capable of detecting the known splice variants in this region (Dautzenberg et al., 1999). PCR-amplified products were subjected to Southern blot analysis using a ${ }^{32} \mathrm{P}$ labeled oligonucleotide probe designed to recognize all splice variants in this region. This revealed a single band at the size expected for the prototype $\mathrm{N}$ terminal of the receptor (data not shown). This was confirmed by DNA sequencing of PCR products.

To determine whether OLP express high-affinity PACAPbinding sites and to investigate their characteristics, the ligandbinding profile was determined on intact cells. Cultured OLP were incubated with ${ }^{125}$ I-PACAP-27 in the presence and absence of increasing ligand concentrations of PACAP-27, PACAP-38, and VIP. Specific binding of ${ }^{125}$ I-PACAP-27 was $\sim 1500 \mathrm{cpm} /$ 100,000 cells in these cultures. PACAP-38 was found to be the most potent displacer $\left(\mathrm{IC}_{50}, 1.2\right.$ pM; Fig. 5A). PACAP-27 exhibited a $>100$-fold lower affinity than did PACAP-38 ( IC $\left._{50}, 0.3 \mathrm{nM}\right)$, whereas VIP was unable to displace ${ }^{125} \mathrm{I}$-PACAP $\left(\mathrm{IC}_{50}>1 \mu \mathrm{M}\right)$. These observations indicate that OLP express a high-affinity PACAP-preferring binding site conforming to the $\mathrm{PAC}_{1}$ receptor (Hashimoto et al., 1993).

To determine whether OLP express PACAP receptors that are functionally coupled to a cAMP second messenger system, cells were treated with increasing concentrations of neuropeptides in the presence of the phosphodiesterase inhibitor IBMX $(10 \mu \mathrm{M})$. Under these conditions, PACAP-38 elevated cAMP levels to a maximum fivefold induction at $1 \mathrm{~nm}$ (Fig. 6A). VIP also increased cAMP levels, but only at concentrations of $100 \mathrm{~nm}$ or higher. Overall, the analyses by Northern blot, RT-PCR, radioligand binding, and cAMP assay indicate that freshly purified OLP 

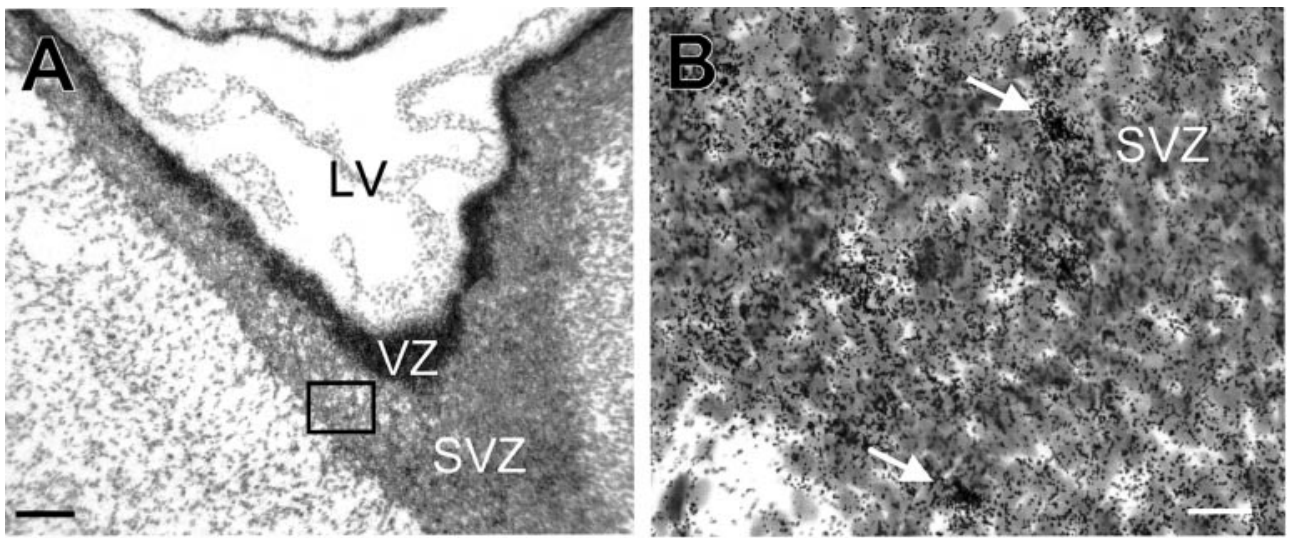

Figure 1. $A-D$, In situ hybridization of $\mathrm{PAC}_{1}$ receptor mRNA in sagittal sections containing the anterior regions of ventricular and subventricular zones of the lateral ventricle. $A, C$, Low magnification of PAC $_{1}$ mRNA signals. $B, D$, High magnification of boxed regions of $A$ and $C$, respectively, showing localized clusterings of silver grains (arrows). E, F, Low and high magnifications, respectively, of a nearby section showing hybridization to a $\mathrm{PAC}_{1}$ receptor sense probe. The boxed region of $E$ is shown in $F$. $L V$, Lateral ventricle. Scale bars: $A, C, E, 50 \mu \mathrm{m} ; B$, $D, F, 16 \mu \mathrm{m}$.
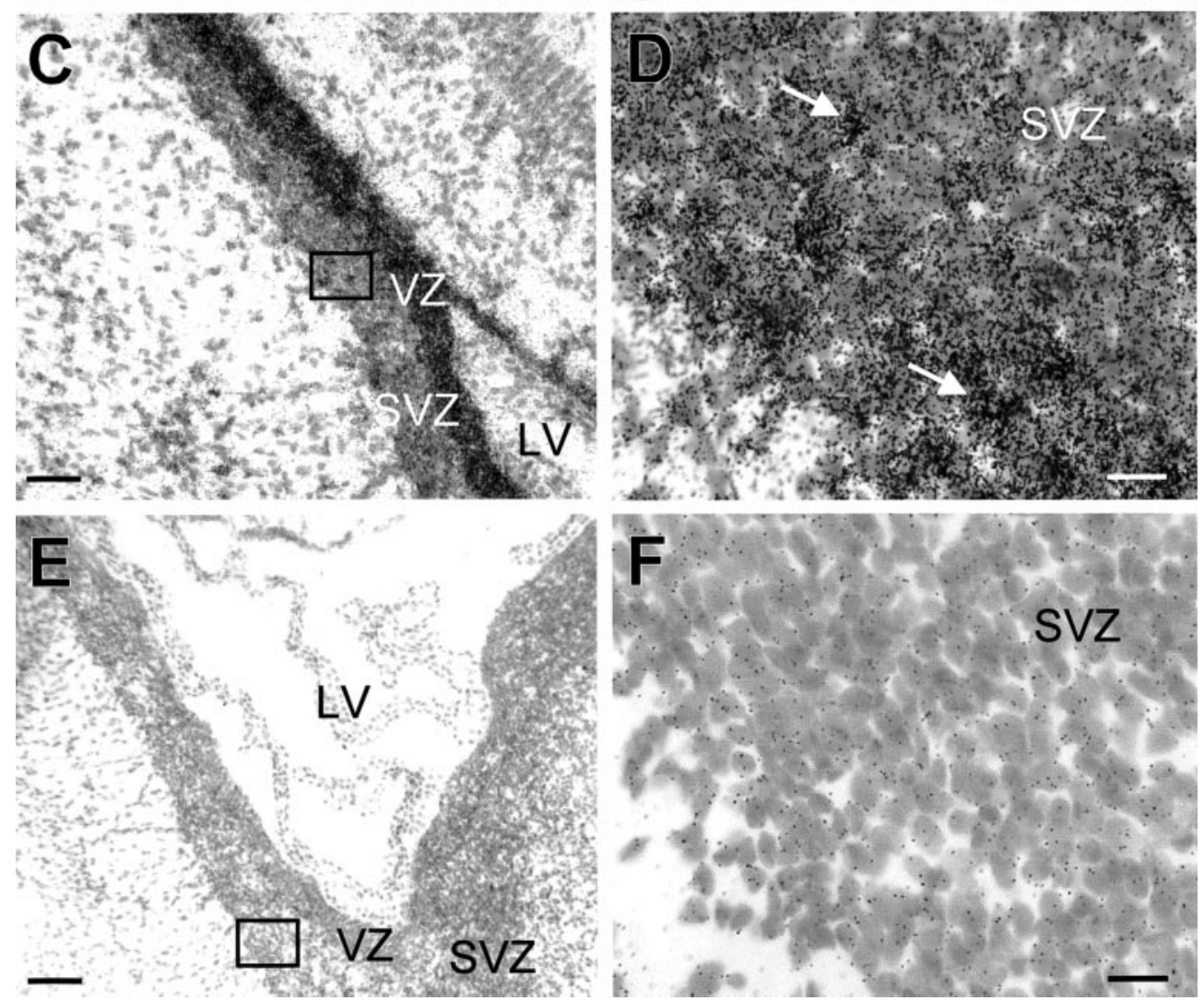

express a functional PACAP-preferring $\mathrm{PAC}_{1}$ receptor that couples moderately to a cAMP messenger system.

\section{PACAP receptor expression during oligodendrocyte maturation in culture}

Purified OLP mature in culture with a time course similar to that observed in vivo based on their morphology and their temporal expression of OL stage-specific markers (Reynolds and Wilkin, 1990; Hardy and Reynolds, 1993). After initial overnight culture, cells show a bipolar phenotype without obvious differentiation features (Fig. 3A). Twenty-four hours later (day 2), primary extension processes have been initiated in a majority of cells. These cells are referred to as "multipolar pre-OL" (Fig. 3B). On day 5 , a majority of cells bore multipolar processes with primary and secondary branching (Fig. 3C, "immature OL"). After $10 \mathrm{~d}$ in culture, most cells are "mature OL," exhibiting primary, secondary, and tertiary processes, and become highly refringent under the microscope (Fig. 3D).
During this course of OLP maturation, PACAP receptors were examined by radioligand binding and displacement and by cAMP assay. As bipolar progenitors progressed to the multipolar pre-OL stage, a significant $30 \%$ reduction of the total available ${ }^{125} \mathrm{I}$ PACAP-binding sites per 100,000 cells was observed (Fig. 5B). In addition, the affinity of PACAP-27 increased dramatically $\left(\mathrm{IC}_{50}\right.$, 300 pM after initial overnight culture vs 11 pm after $48 \mathrm{hr}$ ). VIP was still incapable of displacing ${ }^{125}$ I-PACAP binding at this stage. As OL reached a more differentiated stage (day 5), the number of total ${ }^{125}$ I-PACAP-binding sites was reduced further and exhibited similar high affinity for PACAP-38 and PACAP-27 $\left(\mathrm{IC}_{50} \sim 1\right.$ $\mathrm{pM})$. At this stage, VIP first became capable of displacing a small portion of the total PACAP-binding sites (Fig. 5C). Later, in 10 -d-old OL cultures, VIP displaced $\sim 45 \%$ of the total binding sites, whereas $55 \%$ of the binding sites were specific for PACAP ligands (Fig. 5D).

To determine whether these changes in PACAP-binding char- 


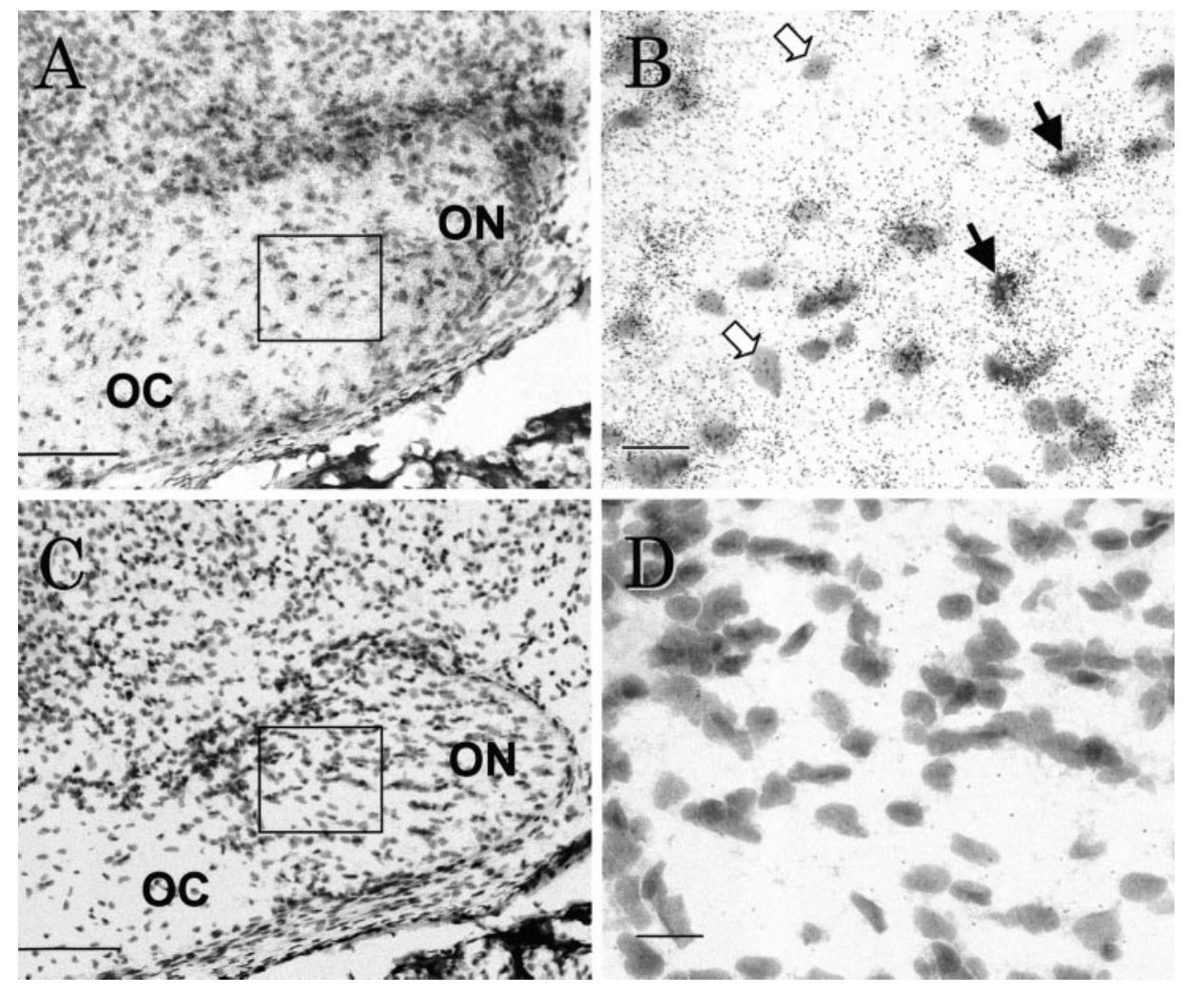

Figure 2. In situ hybridization of a sagittal section showing clusterings of $\mathrm{PAC}_{1}$ receptor gene transcripts over individual cells in an area containing the optic chiasm $(O C)$ and adjoining optic nerve $(O N)$. $A$, Low-magnification photomicrograph of a section hybridized with the $\mathrm{PAC}_{1}$ riboprobe. $B$, High magnification of the boxed area in $A$. Solid arrows point to dense accumulations of silver grains over individual cells around the junction of the optic chiasm and optic nerve. Open arrows point to cells in the same area that lack specific hybridization signals. $C, D$, Low and high magnifications, respectively, of a nearby section showing hybridization to a $\mathrm{PAC}_{1}$ receptor sense probe. The boxed area in $C$ is shown in $D$. Scale bars: $A, C, 50 \mu \mathrm{m} ; B, D, 16 \mu \mathrm{m}$.
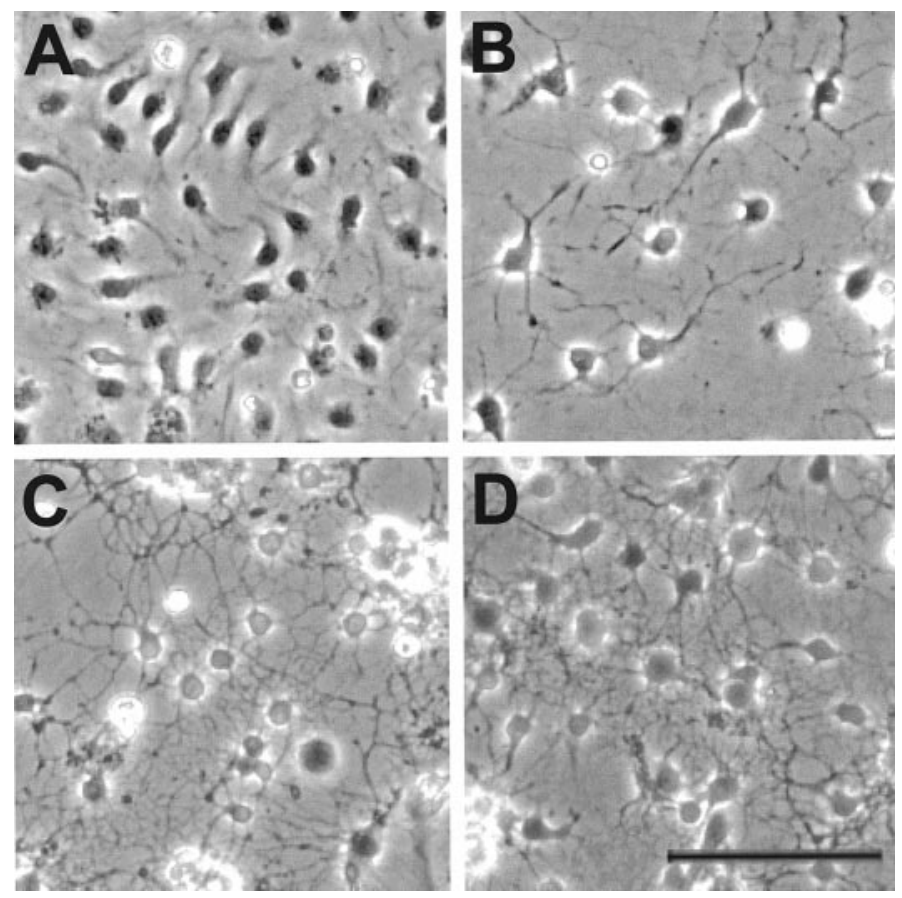

Figure 3. Phase-contrast photomicrographs illustrating morphological changes in cultured developing OL. Cells were cultured in DMEM and F12 containing $10 \%$ fetal bovine serum for $1 \mathrm{~d}$ (OLP; $A$ ), $2 \mathrm{~d}$ (multipolar pre-OL; $B$ ), $5 \mathrm{~d}$ (immature OL; $C$ ), and $10 \mathrm{~d}$ (mature OL; $D$ ). Scale bar, $50 \mu \mathrm{m}$.

acteristics were reflected in the ability of peptides to stimulate adenylate cyclase, peptide-induced changes in cAMP levels were determined in more-differentiated OL and compared with that in less-differentiated OLP. PACAP-38 still exhibited a dose- dependent increase in cAMP levels in 10-d-old cultures, but the potency and maximum degree of stimulation were much lower than that in progenitors (Fig. 6B). The radioligandbinding and cAMP induction data indicate that there is a change in the characteristics of VIP and PACAP receptors as OL mature. OLP express essentially a PACAP-preferring $\mathrm{PAC}_{1}$ receptor, with moderate coupling to cAMP production, whereas more-differentiated OL begin to express receptors for VIP and PACAP that couple poorly to cAMP production. We also performed the RT-PCR analysis on the N-terminal (ligand-binding) domain of the $\mathrm{PAC}_{1}$ receptor in differentiated OL. Like in OLP, this did not reveal splice variants shown to also bind VIP with high affinity (Dautzenberg et al., 1999) (data not shown). Thus, the emergence of VIP-binding sites in differentiated OL does not appear to be explained by splice variants in this region of the $\mathrm{PAC}_{1}$ receptor.

\section{Effect of PACAP on DNA synthesis}

Freshly isolated OLP undergo proliferation for $\sim 48-72 \mathrm{hr}$ in the presence of $10 \%$ fetal bovine serum. Initial experiments using these culture conditions indicated that overnight treatment with PACAP-38 significantly induced proliferation, but only at concentrations of $10^{-7} \mathrm{M}$ or higher (data not shown). In subsequent experiments, the concentration of serum was lowered to $2 \%$ (to decrease basal proliferation), and the PACAP treatment period was extended for a total of $3 \mathrm{~d}$. These conditions unmasked a much more potent action of PACAP on DNA synthesis, with significant stimulation observed at $10^{-10} \mathrm{M}$ (Fig. 7). A maximum $80 \%$ increase in $\left[{ }^{3} \mathrm{H}\right]$ thymidine incorporation was observed in the presence of $100 \mathrm{~nm}$ PACAP-38. FGF-2, a known OLP mitogen (McKinnon et al., 1990), also increased DNA synthesis approximately twofold under these conditions.

To determine whether PACAP specifically stimulated DNA synthesis in OLP rather than in contaminating cell types in 


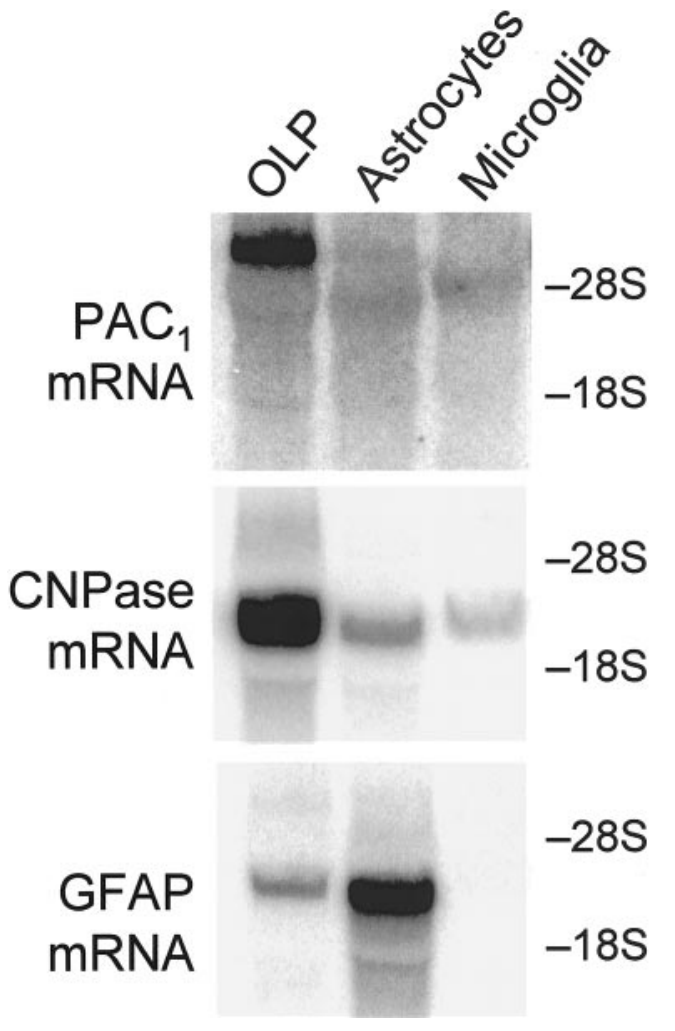

Figure 4. $\mathrm{PAC}_{1}$ receptor gene expression in purified cultures of OLP, astrocytes, and microglia. A Northern blot was prepared containing $30 \mu \mathrm{g}$ of total RNA from cultures of each cell type. The blot was sequentially hybridized with the following ${ }^{32} \mathrm{P}$-labeled cDNA probes: $\mathrm{PAC}_{1} \mathrm{cDNA}$ (top), CNPase (OLP marker; middle), and GFAP (astrocyte marker; bottom). The strong and weak signals for CNPase and GFAP, respectively, in lane 1 (left lane) indicate that OLP cultures were highly enriched for OLP and contained few contaminating astrocytes. In contrast to the strong signal for $\mathrm{PAC}_{1}$ mRNA in OLP, cultures of purified astrocytes

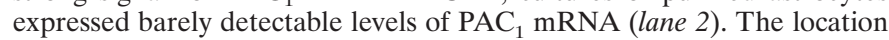
of the $28 \mathrm{~S}$ and $18 \mathrm{~S}$ ribosomal RNA bands, visualized by UV transillumination of the ethidium bromide-stained gel, is indicated to estimate approximately the sizes of the hybridizing transcripts

these cultures, a double-labeled immunocytochemistry analysis was performed. The BrdU-labeling index was determined in OLP cells treated for $18 \mathrm{hr}$ with either $100 \mathrm{~nm}$ PACAP or control medium in the presence of $10 \%$ fetal bovine serum. OLP were detected in this assay with $\mathrm{O} 4$, whereas astrocytes were detected with anti-GFAP. Under control conditions, approximately half of O4-staining cells (OLP) incorporated BrdU (Fig. 8A-C), whereas in PACAP-treated cultures, a much higher proportion of O4+ cells incorporated BrdU (Fig. $8 D-F)$. Very few astrocytes incorporated BrdU either in control cultures (Fig. 8J,K) or in those treated with PACAP (data not shown). ED-1-labeled microglia were extremely rare. Counting of individual cells after drug treatment indicated that PACAP treatment increased the percent of $\mathrm{O} 4+$ cells incorporating BrdU from $52 \pm 6$ to $79 \pm 4 \%$ (mean $\pm \mathrm{SD} ; p<$ $0.001)$. This corresponded to a $52 \%$ increase in DNA synthesis over control. Similar to the untreated control cells, very few GFAP + cells and virtually no ED-1+ microglia incorporated BrdU after PACAP treatment (data not shown). This precluded a reliable determination of the labeling index in astrocyte progenitors or microglia.

\section{PACAP effects on myelinogenesis: in vitro} differentiated $\mathrm{OL}$ cultures and ex vivo cerebellar slices

Myelinogenesis was examined by measuring the incorporation of radiolabeled sulfate into sulfatides (an essential lipid in the formation of myelin membrane) during the final $2 \mathrm{~d}$ of a $14 \mathrm{~d}$ treatment period with peptides. Two models for myelinogenesis were used in these experiments: (1) differentiated OL in culture (in vitro assay) and (2) cerebellar slices (ex vivo). For in vitro assays, OLP were precultured for $10 \mathrm{~d}$ to allow them to mature into multipolar OL. Immunohistochemical analysis (data not shown) and previous work have demonstrated that OL at this stage are immunopositive for myelin basic protein (Reynolds and Wilkin, 1990). These cultures were treated daily with different concentrations of PACAP for $14 \mathrm{~d}$. Anti-GC antibodies, shown previously to inhibit myelinogenesis in cultured cells and slice preparations (Rome et al., 1986; Notterpek et al., 1993), and PDGF were used as controls. PACAP-38, at concentrations of 1 nM and $0.1 \mu \mathrm{M}$, was found to reduce membrane sulfatide synthesis by $\sim 40$ and $50 \%$, respectively (Fig. $9 A$ ). Anti-GC also decreased sulfate incorporation, whereas treatment with PDGF (10 ng/ml) resulted in increased sulfatide synthesis.

To confirm the peptide effects on sulfatide synthesis in purified OL, studies were repeated using the cerebellar explant system (Fig. 9B). As observed in isolated cells, sulfate incorporation was stimulated by PDGF and inhibited by anti-GC antibodies. PACAP-38 was found to trigger a potent inhibition of sulfatide formation in cerebellar slices. A treatment with PACAP during the final week only still reduced sulfate incorporation (data not shown), suggesting that PACAP acted on OL at a later developmental stage in slice cultures. Surprisingly, the 2 week treatment with PACAP was not able to block the stimulatory effect of PDGF (data not shown).

\section{DISCUSSION}

The studies reported here implicate the neuropeptide PACAP as a newly defined factor potentially involved in OL development in the neonatal rat brain. That PACAP might be involved in OL development was suggested by the fact that this peptide is widely expressed in neurons in the early postnatal rat brain (Nielsen et al., 1998b; Skoglosa et al., 1999). We found that gene expression for a PACAP-specific receptor $\left(\mathrm{PAC}_{1}\right)$ was abundant in the postnatal $\mathrm{VZ}$ and $\mathrm{SVZ}$, germinal regions that give rise primarily to oligodendrocytes and astrocytes (Paterson et al., 1973; Levison and Goldman, 1993; Parnavelas, 1999), and that $\mathrm{PAC}_{1}$ gene transcripts were localized over specific cells in the optic chiasm and adjoining optic nerve (Fig. 2). OLP in the latter structures are believed to give rise to the oligodendrocyte lineage in the optic nerve (Small et al., 1987). Although a number of groups have examined possible roles for PACAP in astroglial function, no studies have appeared so far that indicate that PACAP receptors are expressed in OL or OLP or that suggest a role for PACAP in OL development. Using purified cultures of specific glial cell subtypes, we showed by Northern analysis, radioligand binding, and second messenger assay that OLP express functional PACAP-preferring $\mathrm{PAC}_{1}$ receptors. These were found to be moderately coupled to cAMP production. Then, using both cultured OLP and cerebellar explant models, we showed that PACAP regulated two aspects of oligodendrocyte development. First, it enhanced DNA synthesis, and second, it inhibited sulfatide synthesis. These findings suggest two potential actions of PACAP in the temporal and spatial control of OL proliferation and myelin production in the developing brain. 

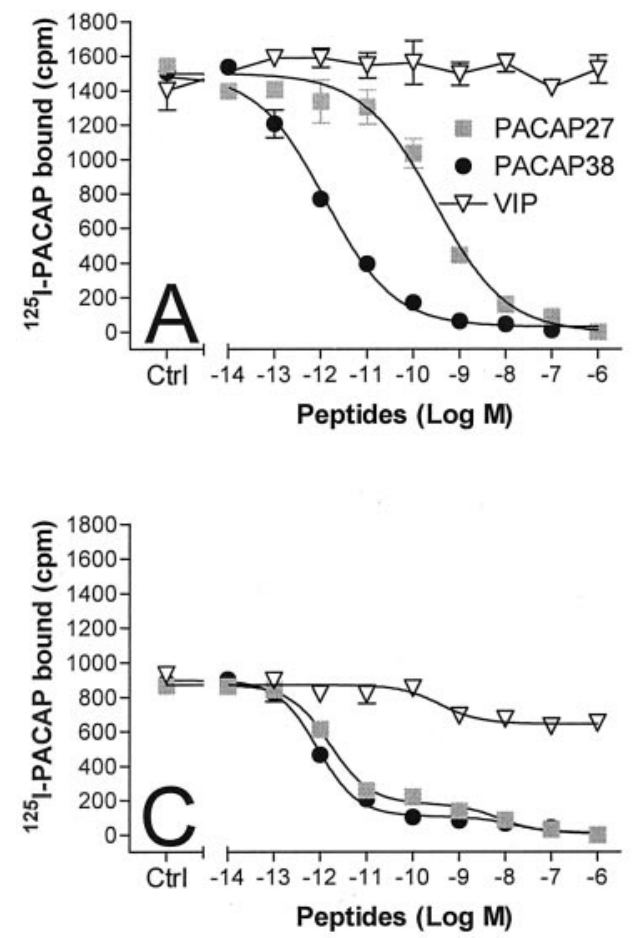

Although PACAP was able to induce cAMP synthesis in freshly isolated OLP, the signaling pathway used by PACAP to stimulate OLP proliferation is still uncertain. Low concentrations of cAMP analogs were reported to be mitogenic in cultured
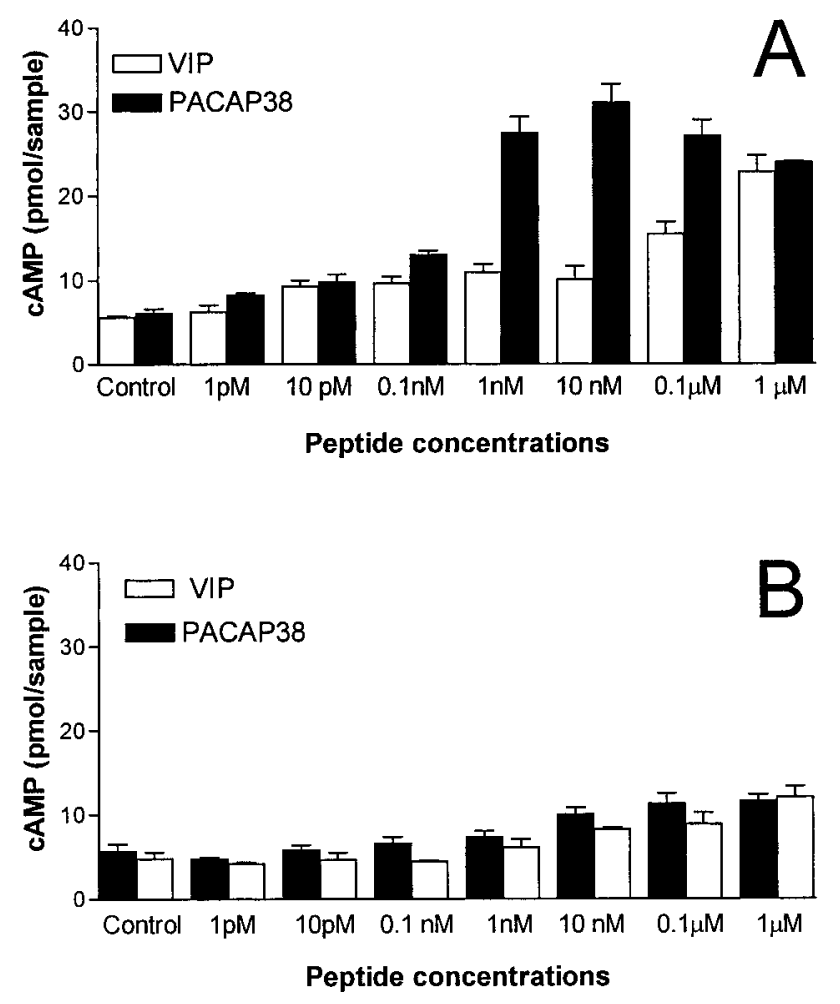

Figure 6. Neuropeptide-induced cAMP levels in OLP $(A)$ and in OL allowed to differentiate for $10 \mathrm{~d}$ in culture $(B)$. Cells were pretreated with IBMX $(10 \mu \mathrm{M})$ for $20 \mathrm{~min}$ followed by neuropeptide treatment for another 20 min. PACAP-38 and VIP were used at the specified concentrations from $1 \mathrm{pM}$ to $1 \mu \mathrm{M}$.

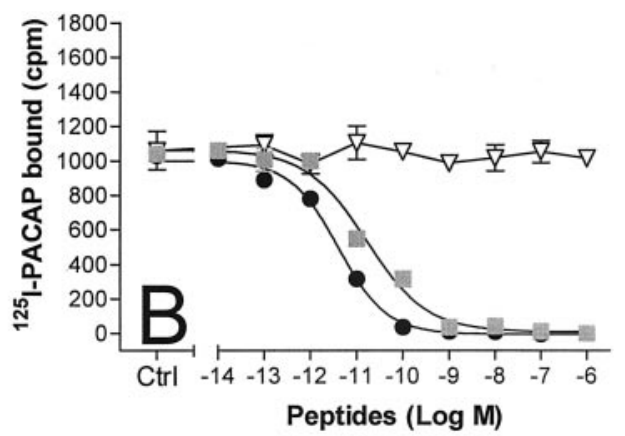

Figure 5. Displacement of ${ }^{125}$ I-PACAP binding by PACAP analogs on isolated cells at different stages of maturation (corresponding to the stages in Fig. 3). A, OLP. $B$, Multipolar pre-OL. $C$, Immature OL. $D$, Mature multipolar OL. Displacements were performed in triplicate as indicated in Materials and Methods. At least three independent experiments were performed for each of the four maturation stages. Cell number was determined in each set of experiments to convert the raw binding data into counts per minute bound per 100,000 cells. Binding curves were estimated using sigmoidal or two-site-displacement equations and computerized with Graphprism software. Ctrl, Control.

Peptides (Log M)
Schwann cells (Raff et al., 1978). However, similar studies by the same group did not reveal mitogenic actions of cAMP analogs on OL precursors isolated from neonatal rat optic nerve (Hart et al., 1989). In addition to the cAMP pathway, $\mathrm{PAC}_{1}$ receptors are known to regulate cell proliferation and/or survival via MAP kinase, phospholipase D, and phosphatidylinositol 3-kinase and other signaling cascades (Morisset et al., 1995; Villalba et al., 1997; Lelièvre et al., 1998). Interestingly, PACAP has been shown to either stimulate or inhibit proliferation, depending on the cell type. For example, although we showed here that PACAP simulated OLP proliferation, we have shown previously that PACAP

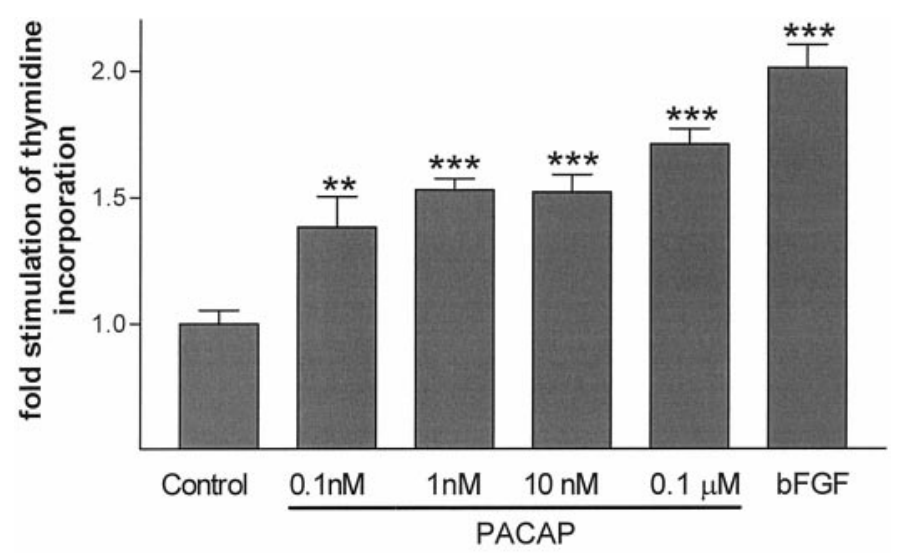

Treatments

Figure 7. PACAP and FGF-2-induced DNA synthesis in cultured OLP. Freshly isolated cultures of OLP were preincubated for $1 \mathrm{~d}$ in medium containing $2 \%$ fetal bovine serum and then treated for $3 \mathrm{~d}$ with PACAP-38 at the indicated concentrations and FGF-2 $(10 \mathrm{ng} / \mathrm{ml})$. $\left[{ }^{3} \mathrm{H}\right]$ Thymidine was added during the final $14 \mathrm{hr}$ of peptide treatment. $\left[{ }^{3} \mathrm{H}\right]$ Thymidine incorporation in control cultures was $\sim 7000 \mathrm{cpm} /$ well. Data were analyzed by ANOVA $\left(* *\right.$ and ${ }^{* * *}$, values significantly different from control at $p<0.05$ and 0.005 , respectively). 

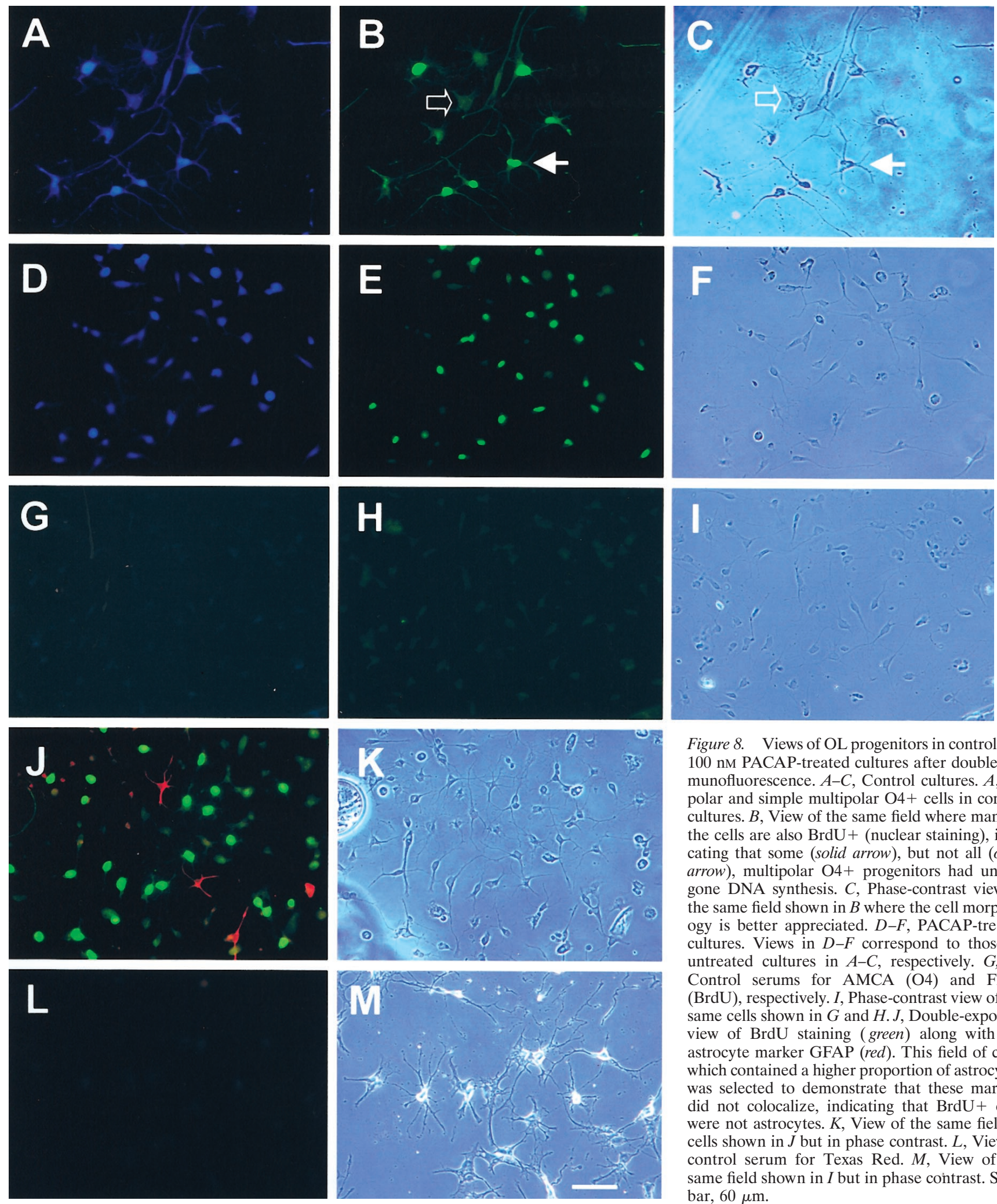

Figure 8. Views of OL progenitors in control and $100 \mathrm{~nm}$ PACAP-treated cultures after double immunofluorescence. $A-C$, Control cultures. $A$, Bipolar and simple multipolar $\mathrm{O} 4+$ cells in control cultures. $B$, View of the same field where many of the cells are also BrdU+ (nuclear staining), indicating that some (solid arrow), but not all (open arrow), multipolar $\mathrm{O} 4+$ progenitors had undergone DNA synthesis. $C$, Phase-contrast view of the same field shown in $B$ where the cell morphology is better appreciated. $D-F$, PACAP-treated cultures. Views in $D-F$ correspond to those of untreated cultures in $A-C$, respectively. $G, H$, Control serums for AMCA (O4) and FITC (BrdU), respectively. I, Phase-contrast view of the same cells shown in $G$ and $H$. J, Double-exposure view of BrdU staining (green) along with the astrocyte marker GFAP (red). This field of cells, which contained a higher proportion of astrocytes, was selected to demonstrate that these markers did not colocalize, indicating that BrdU+ cells were not astrocytes. $K$, View of the same field of cells shown in $J$ but in phase contrast. $L$, View of control serum for Texas Red. $M$, View of the same field shown in $I$ but in phase contrast. Scale bar, $60 \mu \mathrm{m}$.

inhibited DNA synthesis in neural precursors isolated from the hindbrain portion of the neural tube of embryonic day 10.5 (E10.5) mice (Waschek et al., 1998). Another group showed that PACAP stimulated the proliferation of E15.5 rat sympathetic neuroblasts, whereas it inhibited the proliferation of E13.5 cortical neuroblasts (Lu and DiCicco-Bloom, 1997; DiCicco-Bloom et al., 2000). Cell-specific intracellular signaling systems and receptor-coupling mechanisms may thus play an important role in regulating the proliferative actions of PACAP.

The ability of PACAP to inhibit myelinogenesis was demonstrated in initial experiments using cultured OLP undergoing differentiation. It has been shown previously that as OLP differ- 

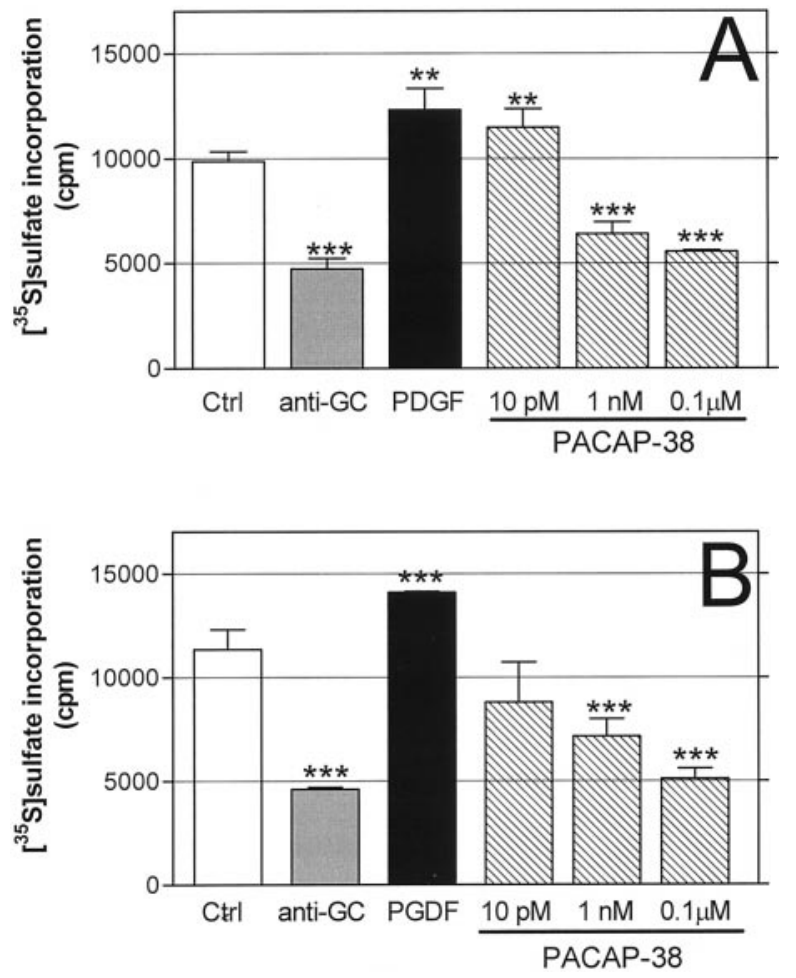

Figure 9. Modulation of myelinogenesis by PACAP and various treatments in differentiating OL in culture $(A)$ and in cerebellar slices $(B)$. After $7 \mathrm{~d}$ of differentiation in culture, the following were added: PACAP (at the indicated concentrations), PDGF (10 $\mathrm{ng} / \mathrm{ml})$, and anti-GC antibody $(15 \mu \mathrm{l} / \mathrm{ml})$. Drugs additions were repeated every other day for a period of 2 weeks. Myelinogenesis was examined during the final $2 \mathrm{~d}$ of treatment by measuring sulfate incorporation into sulfatides as described in Materials and Methods. Three independent experiments were performed, each in triplicate. Statistical analysis was by ANOVA (** and ***, values significantly different from respective control at $p<0.05$ and 0.005 , respectively).

entiate in culture, they show the characteristic morphological changes shown here (Fig. 3D), as well as increased expression of markers characteristic of myelinating cells (GC and MBP), and reduced expression of GD3 (characteristic of immature precursors) (Hardy and Reynolds, 1991). To confirm the data obtained in cultured OL, similar experiments were conducted on cerebellar slice cultures in which myelination of axons has been demonstrated previously (Notterpek et al., 1993). Again, PACAP potently inhibited sulfate incorporation. Likewise, the reported effect of GC antibodies on sulfate incorporation was recapitulated in the cerebellar slice cultures. The fact that PACAP inhibited sulfatide synthesis in purified OL cultures suggests that PACAP acted in slice cultures directly on OL rather than indirectly on another cell type.

It was interesting that PDGF stimulated sulfatide synthesis in OL cultures and cerebellar slices. PDGF also stimulated DNA synthesis in our OLP cultures (data not shown). PDGF is a well known mitogen but also permits OL differentiation (Bögler et al., 1990). One possible explanation for this apparent dual action of PDGF is that developing OL change their response to PDGF with time. The differing actions of PACAP and PDGF on myelinogenesis might thus reflect differences in modulation by external factors or, alternatively, by intrinsic differences in the precise mechanisms of their mitotic actions, for example, promotion of symmetric versus asymmetric division (Ibarrola et al., 1996). A third possibility is that these peptides have separate actions on oligodendrocyte maturation that are unrelated to their effects on proliferation. A separate inhibitory action of PACAP on maturation is supported by the fact that treatment of cerebellar slices with PACAP during the final week only (i.e., during the third week in vitro) was still able to inhibit sulfatide synthesis (data not shown). It seems likely that OLP proliferation would be minimal during this time.

The intracellular signaling pathway used by PACAP to inhibit myelinogenesis is also uncertain. PACAP moderately increased cAMP production in freshly isolated OLPs, but the degree of induction clearly decreased with maturation in culture. The relative loss in the ability of PACAP to increase cAMP production in differentiated OL was accompanied by a reduction in receptor number and a change in binding characteristics. Progenitors expressed high-affinity binding sites that specifically bound PACAP38, whereas differentiated OL exhibited a lower level of PACAPbinding sites that did not discriminate between PACAP-27 and PACAP-38. In addition, VIP did not compete with radioiodinated PACAP binding in OLP, whereas in differentiated OL, almost half of the available ${ }^{125}$ I-PACAP-binding sites were displaced by subnanomolar concentrations of VIP. Specifically, a switch from predominantly PACAP-preferring receptors to VIP and PACAP receptors was observed as OLP differentiated into more mature OL. This observation is reminiscent of previous findings of VIP and PACAP receptor shifts during neuroblastoma cell differentiation (Lelièvre et al., 1996; Waschek et al., 1997). A differential expression of receptors for thyroid hormone (T3) during OL maturation has also been described previously (Carre et al., 1998). Briefly, OLP expressed primarily a T3 receptor variant $(\alpha 2)$ that did not bind $\mathrm{T} 3$, whereas a different receptor form $(\beta 1)$ that binds $\mathrm{T} 3$ became expressed as OL matured.

The significance of the apparent shift in PACAP receptor pharmacology with OLP maturation in culture and the mechanism mediating the shift are unknown. We found that the $\mathrm{PAC}_{1}$ receptor gene continued to be expressed as OL differentiated (data not shown), suggesting that at least some of the binding was caused by expression of the same $\mathrm{PAC}_{1}$ gene. Because the $\mathrm{PAC}_{1}$ receptor has at least eight different splice variants, differing in their coupling and relative affinities for PACAP analogs, one can imagine that a shift in splice form might result in an enhanced affinity for VIP and/or activation of alternate signaling pathways. We did not detect in OL cultures any of the splice variants in the $\mathrm{N}$-terminal extracellular part of $\mathrm{PAC}_{1}$. This receptor domain has been shown to regulate the relative affinity for VIP and PACAP agonists (Dautzenberg et al., 1999). We have not yet attempted to detect splice variants in either the third intracellular loop or the fourth transmembrane domain. These variants have been shown to couple the $\mathrm{PAC}_{1}$ receptor to alternative signaling pathways, although they do not seem to change the receptor affinity for VIP (Spengler et al., 1993; Chatterjee et al., 1996). Thus, several questions remain regarding the receptor forms and signaling pathways that mediate the actions of PACAP in OL development.

It is worth noting that although $\mathrm{PAC}_{1}$ gene expression was easily detectable in cultured OLP by Northern analysis on total RNA, the same assay did not clearly reveal detectable $\mathrm{PAC}_{1}$ gene expression in equivalent amounts of RNA from cultured astrocytes or microglia (Fig. 4). However, as discussed previously, others have detected $\mathrm{PAC}_{1}$ mRNA in these other glial cell types by more-sensitive RT-PCR assays (Grimaldi and Cavallaro, 1999; Kim et al., 2000). Furthermore, $\mathrm{PAC}_{1}$ receptors appear to medi- 
ate some of the actions of PACAP on cultured astrocytes (Figiel and Engele, 2000) and on cultured microglia (Kim et al., 2000). Thus, our results do not imply that $\mathrm{PAC}_{1}$ receptors are not present in these other glial cell types.

What is the importance of the proposed PACAP actions on OLP proliferation and myelinogenesis in normal development and disease? We speculate that the inhibitory action of PACAP on myelinogenesis is necessary to delay myelination, for example, to allow time for synaptic contacts to be established and mature. Interestingly, the expression of PACAP is strongly upregulated in several models of nerve regeneration (Zhang et al., 1996; Z hou et al., 1999; for review, see Zigmond, 1997). PACAP might thus be a factor used to stimulate OLP proliferation after nerve injury (Gensert and Goldman, 1997; McTigue et al., 1998). Subsequently, PACAP might delay myelinogenesis to allow time for the nerve to reinnervate its targets. Finally, the proliferative action of PACAP on OLP may be relevant in CNS tumorigenesis and tumor progression because glioblastomas, including oligodendrocytomas, commonly express PAC and VIP receptors (Vertongen et al., 1995).

\section{REFERENCES}

Arimura A (1998) Perspectives on pituitary adenylate cyclase activating polypeptide (PACAP) in the neuroendocrine, endocrine, and nervous systems. Jpn J Physiol 48:301-331.

Bernier L, Alvarez F, Norgard EM, Raible DW, Mentaberry A, Schembri JG, Sabatini DD, Colman DR (1987) Molecular cloning of a $2^{\prime}, 3^{\prime}$ cyclic nucleotide $3^{\prime}$-phosphodiesterase: mRNAs with different $5^{\prime}$ ends encode the same set of proteins in nervous and lymphoid tissues. J Neurosci 7:2703-2710.

Bögler O, Wren D, Barnett SC, Land H, Noble M (1990) Cooperation between two growth factors promotes extended self-renewal and inhibits differentiation of oligodendrocyte-type-2 astrocyte (O-2A) progenitor cells. Proc Natl Acad Sci USA 87:6368-6372.

Brenneman DE, Neale EA, Foster GA, d'Autremont SW, Westbrook GL (1987) Nonneuronal cells mediate neurotrophic action of vasoactive intestinal peptide. J Cell Biol 104:1603-1610.

Cardwell MC, Rome LH (1988) RGD-containing peptides inhibit the synthesis of myelin-like membranes by cultured oligodendrocytes. J Cell Biol 107:1551-1559.

Carre JL, Demerens C, Rodriguez-Pena A, Floch HH, Vincendon G, Sarlieve LL (1998) Thyroid hormone receptor isoforms are sequentially expressed in oligodendrocyte lineage cells during rat cerebral development. J Neurosci Res 54:584-594.

Chatterjee TK, Sharma RV, Fisher RA (1996) Molecular cloning of a novel variant of the pituitary adenylate cyclase-activating polypeptide (PACAP) receptor that stimulates calcium influx by activation of L-type calcium channels. J Biol Chem 271:32226-32232.

Chomczynski P, Sacchi N (1987) Single-step method of RNA isolation by acid guanidinium thiocyanate-phenol-chloroform extraction. Anal Biochem 162:156-159.

Cole R, de Vellis J (1989) Preparation of astrocyte and oligodendrocyte cultures from primary rat glial cultures. In: A dissection and tissue culture manual of the nervous system, Chap 26 (Shahar A, de Vellis J, Vernadakis A, Haber B, eds), pp 121-133. New York: Liss.

Dautzenberg FM, Mevenkamp G, Wille S, Hauger RL (1999) N-terminal splice variants of the type I PACAP receptor: isolation, characterization and ligand binding/selectivity determinants. J Neuroendocrinol 11:941-949.

De la Fuente M, Delgado M, Gomariz RP (1996) VIP modulation of immune cell functions. Adv Neuroimmunol 6:75-91.

DiCicco-Bloom E, Deutsch PJ, Maltzman J, Z hang J, Pintar JE, Zheng J, Friedman WF, Zhou X, Zaremba T (2000) Autocrine expression and ontogenetic functions of the PACAP ligand/receptor system during sympathetic development. Dev Biol 219:197-213.

Figiel M, Engele J (2000) Pituitary adenylate cyclase-activating polypeptide (PACAP), a neuron-derived peptide regulating glial glutamate transport and metabolism. J Neurosci 20:3596-3605.

Gensert JM, Goldman JE (1997) Endogenous progenitors remyelinate demyelinated axons in the adult CNS. Neuron 19:197-203.

Grimaldi M, Cavallaro S (1999) Functional and molecular diversity of PACAP/VIP receptors in cortical neurons and type I astrocytes. Eur J Neurosci 11:2767-2772.

Hardy R, Reynolds R (1991) Proliferation and differentiation potential of rat forebrain oligodendroglial progenitors both in vitro and in vivo. Development 111:1061-1080.
Hardy R, Reynolds R (1993) Neuron-oligodendroglial interactions during central nervous system development. J Neurosci Res 36:121-126.

Harmar AJ, Arimura A, Gozes I, Journot L, Laburthe M, Pisegna JR, Rawlings SR, Robberecht P, Said SI, Sreedharan SP, Wank SA, Waschek JA (1998) International Union of Pharmacology. XVIII. Nomenclature of receptors for vasoactive intestinal peptide and pituitary adenylate cyclase-activating polypeptide. Pharmacol Rev 2:265-270.

Hart IK, Richardson WD, Bolsover SR, Raff MC (1989) PDGF and intracellular signaling in the timing of oligodendrocyte differentiation. J Cell Biol 109:3411-3417.

Hashimoto H, Ishihara T, Shigemoto R, Mori K, Nagata S (1993) Molecular cloning and tissue distribution of a receptor for pituitary adenylate cyclase-activating polypeptide. Neuron 11:333-342.

Hu Z, Lelièvre V, Chao A, Zhou X, Waschek JA (2000a) Characterization and mRNA distribution of a clone pituitary adenylate cyclaseactivating polypeptide type I receptor in the frog Xenopus brain. Endocrinology 141:657-665.

Hu Z, Lelièvre V, Tam J, Cheng J, Fuenzalida G, Zhou X, Waschek JA (2000b) Molecular cloning of pituitary adenylyl cyclase activating polypeptide in the frog Xenopus laevis: brain distribution and regulation following castration. Endocrinology 141:3366-3376.

Ibarrola N, Mayer-Proschel M, Rodriguez-Pena A, Noble M (1996) Evidence for the existence of at least two timing mechanisms that contribute to oligodendrocyte generation in vitro. Dev Biol 180:1-21.

Kashima T, Tiu SN, Merrill JE, Vinters HV, Dawson G, Campagnoni AT (1993) Expression of oligodendrocyte-associated genes in cell lines derived from human gliomas and neuroblastomas. Cancer Res 53:170-175.

Kim WK, Kan Y, Ganea D, Hart RP, Gozes I, Jonakait GM (2000) Vasoactive intestinal peptide and pituitary adenylyl cyclase-activating polypeptide inhibit tumor necrosis factor- $\alpha$ production in injured spinal cord and in activated microglia via a cAMP-dependent pathway. J Neurosci 20:3622-3630.

Kong LY, Maderdrut JL, Jeohn GH, Hong JS (1999) Reduction of lipopolysaccharide-induced neurotoxicity in mixed cortical neuron/glia cultures by femtomolar concentrations of pituitary adenylate cyclaseactivating polypeptide. Neuroscience 91:493-500.

Legradi G, Hannibal J, Lechan RM (1998) Pituitary adenylate cyclaseactivating polypeptide-nerve terminals densely innervate corticotropinreleasing hormone-neurons in the hypothalamic paraventricular nucleus of the rat. Neurosci Lett 246:145-148.

Lelièvre V, Becq-Giraudon L, Meunier AC, Muller JM (1996) Switches in the expression and function of PACAP and VIP receptors during phenotypic interconversion in human neuroblastoma cells. Neuropeptides 30:313-322.

Lelièvre V, Pineau N, Du J, Wen CH, Nguyen T, Janet T, Muller JM, Waschek JA (1998) Differential effects of peptide histidine isoleucine (PHI) and related peptides on stimulation and suppression of neuroblastoma cell proliferation. A novel VIP-independent action of PHI via MAP kinase. J Biol Chem 273:19685-19690.

Levison SW, Goldman JE (1993) Both oligodendrocytes and astrocytes develop from progenitors in the subventricular zone of postnatal rat forebrain. Neuron 10:201-212.

Lindholm D, Skoglosa Y, Takei N (1998) Developmental regulation of pituitary adenylate cyclase-activating polypeptide (PACAP) and its receptor 1 in rat brain: function of PACAP as a neurotrophic factor. Ann NY Acad Sci 865:189-196.

Liva SM, Kahn MA, Dopp JM, de Vellis J (1999) Signal transduction pathways induced by GM-CSF in microglia: significance in the control of proliferation. Glia 26:344-352.

Lu N, DiCicco-Bloom E (1997) Pituitary adenylate cyclase-activating polypeptide is an autocrine inhibitor of mitosis in cultured cortical precursor cells. Proc Natl Acad Sci USA 94:3357-3362.

Martin JL, Feinstein DL, Yu N, Sorg O, Rossier C, Magistretti PJ (1992) VIP receptor subtypes in mouse cerebral cortex: evidence for a differential localization in astrocytes, microvessels and synaptosomal membranes. Brain Res 587:1-12.

McCarthy KD, de Vellis J (1980) Preparation of separate astroglial and oligodendroglial cell cultures from rat cerebral tissue. J Cell Biol 85:890-902.

McKinnon RD, Matsui T, Dubois-Dalcq M, Aaronson SA (1990) FGF modulates the PDGF-driven pathway of oligodendrocyte development. Neuron 5:603-614.

McRory J, Sherwood NM (1997) Two protochordate genes encode pituitary adenylate cyclase-activating polypeptide and related family members. Endocrinology 138:2380-2390.

McTigue DM, Horner PJ, Stokes BT, Gauge FH (1998) Neurotrophin-3 and brain-derived neurotrophic factor induce oligodendrocyte proliferation and myelination of regenerating axons in the contused adult rat spinal cord. J Neurosci 18:5354-5365.

Morisset J, Douziech N, Rydzewska G, Buscail L, Rivard N (1995) Cell signaling pathway involved in PACAP-induced AR4-2J cell proliferation. Cell Signal 7:195-205.

Nielsen HS, Hannibal J, Fahrenkrug J (1998a) Embryonic expression of pituitary adenylate cyclase-activating polypeptide in sensory and auto- 
nomic ganglia and in spinal cord of the rat. J Comp Neurol 394:403-415.

Nielsen HS, Hannibal J, Fahrenkrug J (1998b) Expression of pituitary adenylate cyclase activating polypeptide (PACAP) in the postnatal and adult rat cerebellar cortex. NeuroReport 9:2639-2642.

Notterpek LM, Bullock PN, Malek-Hedayat S, Fisher R, Rome LH (1993) Myelination in cerebellar slice cultures: development of a system amenable to biochemical analysis. J Neurosci Res 36:621-634.

Otto C, Zuschratter W, Gass P, Schutz G (1999) Presynaptic localization of the PACAP-type I-receptor in hippocampal and cerebellar mossy fibers. Brain Res Mol Brain Res 66:163-174.

Pantaloni C, Brabet P, Bilanges B, Dumuis A, Houssami S, Spengler D, Bockaert J, Journot L (1996) Alternative splicing in the N-terminal extracellular domain of the pituitary adenylate cyclase-activating polypeptide (PACAP) receptor modulates receptor selectivity and relative potencies of PACAP-27 and PACAP-38 in phospholipase C activation. J Biol Chem 271:22146-22151.

Parnavelas JG (1999) Glial cell lineages in the rat cerebral cortex. Exp Neurol 156:418-429.

Paterson J, Privat A, Ling EA, Leblond CP (1973) Investigation of glial cells in semithin sections. III. Transformation of subependymal cells into glial cells, as shown by autoradiography of $\left[{ }^{3} \mathrm{H}\right]$ thymidine injection into the lateral ventricle of the brain of young rats. J Comp Neurol 149:83-103.

Pincus DW, DiCicco-Bloom EM, Black IB (1990) Vasoactive intestinal peptide regulates mitosis, differentiation and survival of cultured sympathetic neuroblasts. Nature 343:564-567.

Pisegna JR, Wank SA (1993) Molecular cloning and functional expression of the pituitary adenylate cyclase-activating polypeptide type I receptor. Proc Natl Acad Sci USA 90:6345-6349.

Raff MC, Hornby-Smith A, Brockes JP (1978) Cyclic AMP as a mitogenic signal for cultured rat Schwann cells. Nature 273:672-673.

Raff MC, Abney ER, Miller RH (1984) Two glial cell lineages diverge prenatally in rat optic nerve. Dev Biol 106:53-60.

Ranscht B, Clapshaw PA, Price J, Noble M, Seifert W (1982) Development of oligodendrocytes and Schwann cells studied with a monoclonal antibody against galactocerebroside. Proc Natl Acad Sci USA 79:2709-2713

Rawlings SR (1994) PACAP, PACAP receptors, and intracellular signaling. Mol Cell Endocrinol 101:C5-C9.

Rawlings SR, Hezareh M (1996) Pituitary adenylate cyclase-activating polypeptide (PACAP) and PACAP/vasoactive intestinal polypeptide receptors: actions on the anterior pituitary gland. Endocr Rev 17:4-29.

Reynolds R, Wilkin GP (1990) Proliferation of oligodendroglial progenitor cells in developing rat cerebellum in situ. In: Differentiation and functions of glial cells (Alan R, ed), pp 59-60. New York: Liss.

Rome LH, Bullock PN, Chiappelli F, Cardwell M, Adinolfi AM, Swanson D (1986) Synthesis of a myelin-like membrane by oligodendrocytes in culture. J Neurosci Res 15:49-65.

Shibuya I, Kabashima N, Tanaka K, Setiadji VS, Noguchi J, Harayama N, Ueta Y, Yamashita H (1998) Patch-clamp analysis of the mechanism of PACAP-induced excitation in rat supraoptic neurones. J Neuroendocrinol 10:759-768.

Skoff RP, Toland D, Nast E (1980) Pattern of myelination and distribution of neuroglial cells along the developing optic system of the rat and rabbit. J Comp Neurol 191:237-253.
Skoglosa Y, Takei N, Lindholm D (1999) Distribution of pituitary adenylate cyclase activating polypeptide mRNA in the developing rat brain. Brain Res Mol Brain Res 65:1-13.

Small RK, Riddle P, Noble M (1987) Evidence for migration of oligodendrocyte-type-2 astrocyte progenitor cells into the developing rat optic nerve. Nature 328:155-157.

Spengler D, Waeber C, Pantaloni C, Holsboer F, Bockaert J, Seeburg PH, Journot L (1993) Differential signal transduction by five splice variants of the PACAP receptor. Nature 365:170-175.

Vaudry D, Gonzalez BJ, Basille M, Fournier A, Vaudry H (1999) Neurotrophic activity of pituitary adenylate cyclase-activating polypeptide on rat cerebellar cortex during development. Proc Natl Acad Sci USA 96:9415-9420.

Vertongen P, d'Haens J, Michotte A, Velkeniers B, van Rampelbergh J, Svoboda M, Robberecht P (1995) Expression of pituitary adenylate cyclase activating polypeptide and receptors in human brain tumors. Peptides 16:713-719.

Vertongen P, Devalck C, Sariban E, De Laet MH, Martelli H, Paraf F, Helardot P, Robberecht P (1996) Pituitary adenylate cyclase activating peptide and its receptors are expressed in human neuroblastomas. J Cell Physiol 167:36-46.

Villalba M, Bockaert J, Journot L (1997) Pituitary adenylate cyclaseactivating polypeptide (PACAP-38) protects cerebellar granule neurons from apoptosis by activating the mitogen-activated protein kinase (MAP kinase) pathway. J Neurosci 17:83-90.

Waschek JA (1996) VIP and PACAP receptor-mediated actions on cell proliferation and survival. Ann NY Acad Sci 805:290-300.

Waschek JA, Lelievre V, Bravo DT, Nguyen T, Muller JM (1997) Retinoic acid regulation of the VIP and PACAP autocrine ligand and receptor system in human neuroblastoma cell lines. Peptides 18:835-841.

Waschek JA, Casillas RA, Nguyen TB, DiCicco-Bloom EM, Carpenter EM, Rodriguez WI (1998) Neural tube expression of pituitary adenylate cyclase-activating polypeptide (PACAP) and receptor: potential role in patterning and neurogenesis. Proc Natl Acad Sci USA 95:9602-9607.

Yonemasu T, Nakahira K, Okumura S, Kagawa T, Espinosa de los Monteros A, de Vellis J, Ikenaka K (1998) Proximal promoter region is sufficient to regulate tissue-specific expression of UDP-galactose: ceramide galactosyltransferase gene. J Neurosci Res 52:757-765.

Zhang YZ, Hannibal J, Z hao Q, Moller K, Danielsen N, Fahrenkrug J, Sundler F (1996) Pituitary adenylate cyclase activating peptide expression in the rat dorsal root ganglia: up-regulation after peripheral nerve injury. Neuroscience 74:1099-1110.

Zhou X, Rodriguez WI, Casillas RA, Ma V, Tam J, Hu Z, Lelievre V, Chao A, Waschek JA (1999) Axotomy-induced changes in pituitary adenylate cyclase activating polypeptide (PACAP) and PACAP receptor gene expression in the adult rat facial motor nucleus. J Neurosci Res 57:953-961.

Zigmond RE (1997) LIF, NGF, and the cell body response to axotomy. The Neuroscientist 3:176-185.

Zupan V, Hill JM, Brenneman DE, Gozes I, Fridkin M, Robberecht P, Evrard P, Gressens P (1998) Involvement of pituitary adenylate cyclase-activating polypeptide II vasoactive intestinal peptide 2 receptor in mouse neocortical astrocytogenesis. J Neurochem 70:2165-2173. 